\title{
Trends in regional outpatient antibiotic prescription data and interventions in the Dutch-German EURSAFETY HEALTH-NET-project
}

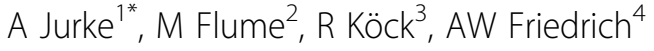 \\ From International Conference on Prevention \& Infection Control (ICPIC 2011) \\ Geneva, Switzerland. 29 June - 2 July 2011
}

\section{Introduction / objectives}

Increasing prescription of broad-spectrum antibiotics is regarded to facilitate selection of multiresistant germs. Surveillance of outpatient antibiotic use might contribute to prevent the spread of Methicillin-resistant $S$. aureus (MRSA) within the EURSAFETY HEALTH-NET. Training sessions on MRSA and antibiotic awareness were offered to general practitioners. A possibility for reimbursement of MRSA eradication therapy in outpatients has been created.

\section{Methods}

Regional data for outpatient prescription of antibiotics (based on Defined Daily Doses (DDD)) were collected by the Association of Statutory Health Insurance Physicians Westphalia-Lippe (KVWL) and analyzed for the years 2002 to 2009. In order to compare the prescription of different antibiotics like fluoroquinolones or mupirocin in the EUREGIO to the whole KVWL region, we used the Cochrane Armitage Trend Test.

\section{Results}

Altogether, a total of 12.2 DDD / day per 1,000 inhabitants (DID) were prescribed in 2002, followed by 12.9 DID, 12.9 DID, 14.4 DID, 13.8 DID, 14.4 DID, 14.7 DID and 14.8 DID from 2003 to 2009, respectively. From 2002 to 2009 the percentage of prescriptions of all antibiotics and of fluorochinolones decreased significantly in EUREGIO relating to the whole KVWL region. In contrast, the number of mupirocin prescriptions increased significantly more in EUREGIO than in KVWL region.

${ }^{1}$ Infectiology and Hygiene, NRW Institute of Health and Work, Münster, Germany

Full list of author information is available at the end of the article

\section{Conclusion}

As desirable, EUREGIO tends to prudent antibiotic use. The increasing number of mupirocin prescription among outpatients reflects the growing demand and, facilitated by new refunding possibilities, the increasing implementation of MRSA eradication therapy in outpatient care.

\section{Disclosure of interest}

None declared.

\section{Author details}

${ }^{1}$ Infectiology and Hygiene, NRW Institute of Health and Work, Münster, Germany. ${ }^{2}$ Prescription Management, Association of Statutory Health Insurance Physicians Westphalia-Lippe, Dortmund, Germany. ${ }^{3}$ Institute of Hygiene, University Hospital, Münster, Germany. ${ }^{4}$ Department of Medical Microbiology, University Medical Centre, Groningen, Netherlands.

Published: 29 June 2011

doi:10.1186/1753-6561-5-S6-P144

Cite this article as: Jurke et al:: Trends in regional outpatient antibiotic prescription data and interventions in the Dutch-German EURSAFETY HEALTH-NET-project. BMC Proceedings 2011 5(Suppl 6):P144.

Submit your next manuscript to BioMed Central and take full advantage of:

- Convenient online submission

- Thorough peer review

- No space constraints or color figure charges

- Immediate publication on acceptance

- Inclusion in PubMed, CAS, Scopus and Google Scholar

- Research which is freely available for redistribution (c) 2011 Jurke et al; licensee BioMed Central Ltd. This is an open access article distributed under the terms of the Creative Commons Attribution License (http://creativecommons.org/licenses/by/2.0), which permits unrestricted use, distribution, and reproduction in any medium, provided the original work is properly cited. 